\title{
老化研究の多面的アプローチ：そこから見えてくる未来
}

\author{
高橋良哉, ${ }^{*}, a$ 樋上賀一b
}

\section{Multidisciplinary Approach to Aging: Future Trends}

\author{
Ryoya Takahashi ${ }^{*, a}$ and Yoshikazu Higami ${ }^{b}$
}

${ }^{a}$ Faculty of Pharmaceutical Sciences, Toho University; 2-2-1 Miyama, Funabashi, Chiba 274-8510, Japan: and ${ }^{b}$ Laboratory of Molecular Pathology and Metabolic Disease, Department of Medical and Life Science, Faculty of Pharmaceutical Sciences, Tokyo University of Science; 2641 Yamazaki, Noda, Chiba 278-8510, Japan.

日本人の平均寿命は，いまだに延び続けている. 厚生労働省の平成 29 年簡易生命表によると, 2017 年の日本人の平均寿命は男性 81.09 歳, 女性は 87.26 歳で過去最高を更新した。100 歳以上の高齢 者人口が年々増え続けおり，「100 歳まで生きる」 が当たり前の時代がもうじき訪れると思われる.

寿命の延長に伴い問題になるのは，高齢者の日常 生活動作（activities of daily living; ADL）と生活の 質（QOL）の低下である。いずれも加齢に伴う身 体・精神機能の低下によってもたらされると考えら れる。

老化関連疾患の発症や進展に密接に係わつている のは，主に「代謝系」，「免疫系」，「脳・神経系」の 加齢に伴う機能低下である．なぜならば，「代謝系」 を抑制するカロリー制限は，加齢に伴う生理機能低 下を防ぎ，高血圧，がんなどの老化関連疾患の発症 を抑制あるいは遅延するからである。また，「免疫 系」は加齢による様々な疾患発症や病態進展の抑制 に重要な役割を果たしている。ささらに，「脳・神経 系」は加齢に伴う神経変性がアルツハイマー病など の認知症発症と密接な関係があるからである. しか し，「代謝」，「免疫」及び「脳・神経」のいずれの 研究についても，その本質はいまだに十分に解明さ れていない。

本誌上シンポジウムでは「老化研究の多面的アプ

$a$ 東邦大学薬学部生化学教室（干274-8510 千葉県船橋 市三山 2-2-1), ${ }^{b}$ 東京理科大学薬学部生命創薬科学科 分子病理 - 代謝学研究室 (下278-8510 千葉県野田市山 崎 2641)

*e-mail: takahasi@phar.toho-u.ac.jp

日本薬学会第 139 年会シンポジウム S17 序文
ローチ：そこから見えてくる未来」と題し，はじめ に，オーガナイザー（高橋良哉）から老化研究の多 面的アプローチの重要性と現状について説明した. 次に，「代謝系」，「免疫系」，「脳・神経系」を専門 とする基礎老化研究の第一人者に, 各分野の最新の 研究について紹介して頂いた。概要は次の通りであ る.

「代謝の老化」は樋上賀一教授（東京理科大学薬 学部）に「カロリー制限による脂肪組織での代謝リ モデリング」と題し, 脂肪組織における脂肪酸合成 関連転写因子（sterol regulatory element binding protein-1c; Srebp-1c) を介した de novo 脂肪酸合成 の活性化, PPAR gamma coactivator 1-alpha（Pgc$1 \alpha)$ 発現六進によるミトコンドリア生合成の克進 とミトコンドリアシグナルペプチダーゼの 1 つであ る mitochondrial intermediate peptidase (Mipep) を介したミトコンドリアの質の改善が抗老化・寿命 延伸に重要であることを明らかにした研究などにつ いて紹介して頂いた。

「免疫の老化」は丸山光生副所長（国立長寿医療 研究センター）に「感染防御と栄養介入の最前線」 と題し， B 細胞分化と免疫老化におけるグアニンヌ クレオチド交換因子 Zizimin2（Ziz2, DOCK11）の 関与についての研究などについて紹介して頂いた.

「脳・神経の老化」は森 望教授（長崎大学医学 部）に「遺伝子発現の精度と統括因子からみる老化 脳制御」と題し，細胞修復やストレス防御系の遺伝 子を駆動し老化ニューロンを保護に関与するといわ れている RE1-silencing transcription factor (REST) の老化脳での重要性などについて論じて頂いた。

高齢者の QOL 低下の原因となる身体機能低下ゃ 
疾患発症の分子メカニズムに関する研究成果は, 健 康維持, 疾患予防と治療, 創薬などを目指した多く の研究の重要な情報となる。本シンポジウムで提供 する「代謝」,「免疫」,「脳・神経」の老化研究の最 新の研究成果は, 科学的な基礎知識に基づいた健康
増進の推進に貢献する薬学の発展に寄与することが 期待される. また, 本企画は, 本学会の研究者, 教 育者，医療関係者のみならず，薬学生にも有益な情 報提供の機会となると考えられる。 